\title{
Sistem Penjadwalan Shift Jaga di PT. Air Mancur Berbasis Web dan SMS Gateway
}

\author{
Anisah Tri Setyowinarti, Yogiek Indra Kurniawan \\ Program Studi Informatika \\ Universitas Muhammadiyah Surakarta (UMS) \\ Surakarta, Indonesia \\ at.setyowina@gmail.com,yogiek@ums.ac.id
}

\begin{abstract}
PT. Air Mancur khususnya bagian pengelolaan penjadwalan karyawan satuan keamanan (security) masih menggunakan sistem lama seperti mengkoordinasi satu persatu kepada setiap karyawan. Sistem lama tersebut dinilai tidak optimal dan tidak efisien. Maka dari itu dibuatlah sebuah sistem penjadwalan shift jaga berbasis web dan sms gateway. Tujuan pembuatan sistem penjadwalan ini untuk memudahkan kepala keamanan dalam mengelola penjadwalan shift jaga di PT. Air Mancur. Sistem penjadwalan shift jaga berbasis web menggunakan metode waterfall, bahasa pemrograman yang digunakan PHP dan tampilan web menggunakan bootstrap, pengelolaan database menggunakan MySQL, sedangkan sms gateway menggunakan Gammu. Pengumpulan data menggunakan teknik observasi, kuesioner dan wawancara. Penelitian ini menghasilkan sebuah aplikasi sistem penjadwalan shift jaga berbasis web dan sms gateway. Sistem ini terdapat beberapa menu diantaranya data pegawai, data log jadwal dan sms gateway. Fitur dalam sistem ini telah valid berdasarkan pengujian blackbox. Hasil pengujian kuesioner $89 \%$ responden mengatakan bahwa sistem penjadwalan shift jaga berbasis web dan sms gateway ini mudah digunakan dan sangat membantu dalam penjadwalan shift jaga di PT. Air Mancur.
\end{abstract}

Kata Kunci: Sistem Informasi, Sistem Penjadwalan, SMS Gateway, Web

\section{Pendahuluan}

Kemajuan teknologi saat ini sangat pesat. Hal ini memudahkan kita mengakses segala informasi, tidak terkecuali dalam penjadwalan shift jaga dalam sebuah perusahaan berbasis website dan Sms Gateway. Sistem penjadwalan adalah kumpulan mekanisme proses yang berjalan sesuai urutan dalam sistem komputer. Sms gateway adalah sistem penghubung antara komputer dengan client melalui sms. Gammu adalah sebuah aplikasi yang digunakan untuk mengkomunikasikan database sms gateway dengan sms device. PT. Air Mancur adalah sebuah perusahaan yang bergerak dalam bidang meracik obat-obatan tradisional. PT. Air Mancur memiliki 17 karyawan Satuan Keamanan (security) yang terbagi menjadi 3 shift jam kerja yaitu shift pagi mulai dari jam 06.00 pagi sampai 14.00 siang, shift siang mulai dari jam 14.00 siang sampai 22.00 malam, dan shift malam mulai dari jam 22.00 malam sampai jam 06.00 pagi.
Permasalahan yang muncul adalah sistem penjadwalan shift jaga di PT. Air Mancur masih menggunakan sistem lama seperti mengkoordinasi satu per satu kepada setiap karyawan. Sistem lama tersebut dirasa kurang optimal karena Kepala Satuan Pengamanan harus koordinasi pada setiap karyawannya. PT tersebut memiliki 16 karyawan laki-laki dan 1 karyawan perempuan divisi Keamanan, Sering kali Kepala Satuan Pengamanan kesulitan dalam mengatur penjadwalan untuk itu dibuatlah sistem penjadwalan shift jaga berbasis website dan SMS Gateway, dengan berbasis website memudahkan Kepala Satuan Keamanan dalam mengatur penjadwalan setiap karyawan dan karyawan dapat mengetahui jadwal yang sudah diatur Kepala Satuan Keamanan. Fasilitas SMS Gateway tersebut karyawan mendapat pemberitahuan melalui sms untuk mengingatkan jadwal shift jaga.

Permasalahan yang timbul dalam jurnal (budi setyawan dkk, 2013) adalah informasi tidak sampai ke semua siswa dan apabila ada pengumuman siswa harus ke kampus untuk melihat pengumuman dipapan pengumuman. Untuk itu dibuatlah layanan sistem informasi berbasis SMS Gateway. Dengan adanya layanan sistem informasi berbasis SMS Gateway tersebut dapat memudahkan siswa dalam mengetahui informasi seputar perkuliahan lebih efektif dan efisien. [1]

Jurnal Supriyono dkk (2016) menjelaskan bahwa SMP Muhammadiyah 1 Kartosuro masih belum memiliki sistem komputerisasi yang mendukung dalam mengelola kehadiran siswa. Banyak siswa yang masuk tanpa keterangan dan tidak adanya tindak lanjut. Orang tua pun tidak dapat mengetahui kehadiran anak-anaknya. Oleh karena itu dibuatlah sistem komputerisasi untuk mengelola kehadiran siswa berbasis SMS Gateway karena sangat mudah digunakan dan biaya sangat murah. [2]

Aswiya dan waryanto (2017) permasalahan dalam skripsinya menjelaskan bahwa tidak efisiennya pendataan jadwal yang masih menggunakan sistem lama, dan sering mengganti jadwal berdampak jadwal yang tepat menjadi sulit terbaca sehingga sulit dalam pengecekan gaji. Maka dari itu muncul ide penulis untuk membuat sistem informasi berbasis website untuk memudahkan admin mendapatkan informasi 
yang efisien. Sistem ini difasilitasi dengan SMS Gateway. SMS Gateway dibuat untuk melihat dan mengganti jadwal, sehingga admin dapat melihat dan mengganti jadwal tanpa mengakses website secara langsung. [3]

Skripsi dari Muchtar (2015) memiliki kendala personel, pengumuman, kurang komunikasi, pembentukan jadwal, dll. Dengan adanya permasalahan tersebut, maka dibuatlah sistem informasi untuk membantu warga mengetahui informasi yang terbaru melalui via SMS, membantu dalam mengatur jadwal rapat, jadwal ronda dan melakukan komputasi denda. [4]

Yogiek Indra Kurniawan (2018) telah menerapkan media promosi sekolah di SMA Negeri Kerjo berbasis website untuk menyelesaikan permasalahan sebelumnya. Dengan adanya website yang telah dibuat maka semua kalangan dapat mengetahui informasi berkaitan dengan SMA Negeri Kerjo melalui website tersebut menjadi lebih efektif. [5]

Sebagian besar penduduk Indonesia memiliki telepon seluler untuk berkomunikasi satu sama lain, untuk itu dibuatlah aplikasi sistem penjadwalan berbasis webiste dan SMS Gateway. Adanya aplikasi sistem penjadwalan shift jaga berbasis website kepala satuan pengamanan dapat mengatur penjadwalan di setiap bulannya dengan mudah dan SMS Gateway untuk memberi informasi jadwal setiap karyawan dengan format yang telah ditentukan. Dengan ini dapat memudahkan Kepala Satuan Keamanan dalam mengatur penjadwalan shift jaga pada PT Air Mancur.

\section{DASAR TEORI DAN TINJAUAN PUSTAKA}

Sistem penjadwalan adalah kumpulan mekanisme proses yang berjalan sesuai urutan dalam sistem komputer. [6]

Sms gateway adalah sistem penghubung antara komputer dengan client melalui sms. Gammu adalah sebuah aplikasi yang digunakan untuk mengkomunikasikan database sms gateway dengan sms device. [7]

\section{METODE}

Penelitian ini menggunakan Metode Waterfall, yang merupakan suatu metode dalam pengembangan perangkat lunak atau sering disebut dengan classic life cycle (Pressman, 2010). [8] Metode Waterfall disajikan pada Gambar 1.

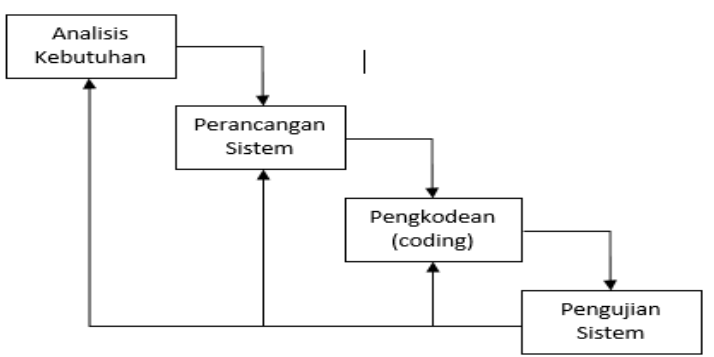

\section{Gambar 1. Metode Waterfall Pembuatan Sistem}

\subsection{Analisis Kebutuhan}

Tahap awal ini merupakan analisis terhadap kebutuhan sistem dimana mencari informasi dari user untuk membuat sistem yang di inginkan oleh user. Tahap ini penulis menggunakan metode wawancara ke PT. Air Mancur.

\subsection{Perancangan Sistem}

Tahap kedua adalah perancangan sistem, dimana proses perancangan sistem ini terdiri dari use case diagram, activity diagram, tabel relasi.

\subsubsection{Use Case Diagram}

Use case adalah sebuah interaksi sederhana yang menjelaskan tentang identifikasi siapa saja yang dapat menggunakan fungsi dalam sistem tersebut dan urutan yang dilakukan oleh sistem tersebut. Use case tersebut hanya memiliki satu aktor yaitu admin.

Admin, memiliki hak penuh yaitu dapat melakukan login, manage data master, manage data jadwal, akses SMS Gateway, logout. Use case diagram ditunjukkan pada Gambar 2.

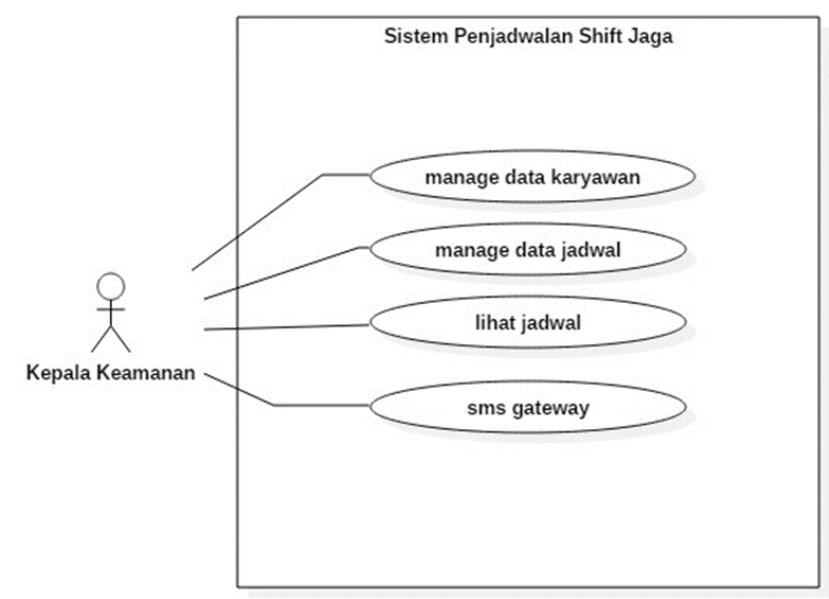

Gambar 2. Use Case Diagram

\subsubsection{Activity Diagram}

Activity diagram adalah sebuah diagram aktivitas dimana dalam diagram tersebut menjelaskan alur kerja antara admin, sistem, dan SMS Gateway. Activity diagram ditunjukkan pada Gambar 3. 


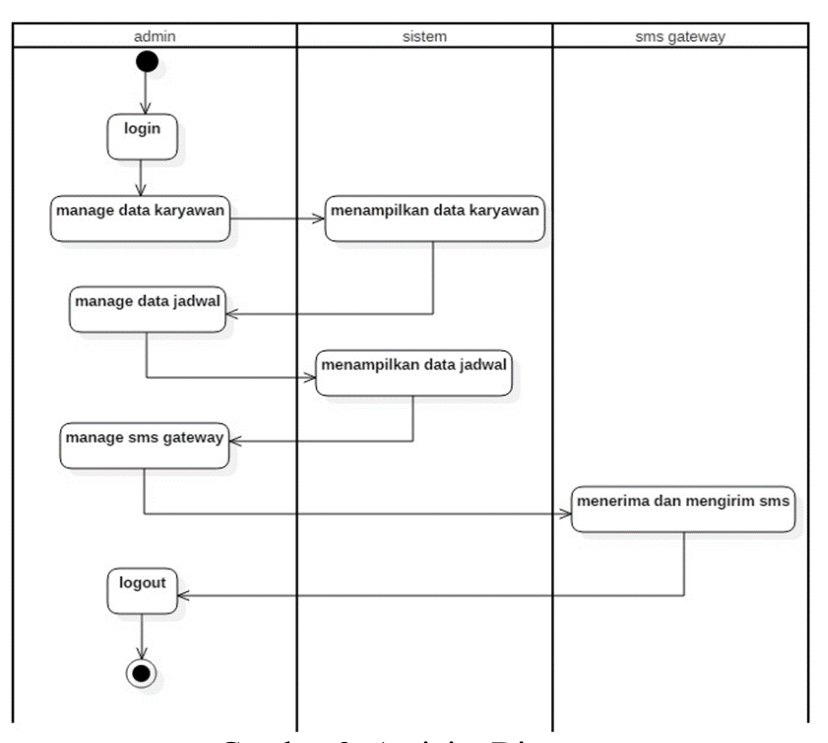

Gambar 3. Activity Diagram

Langkah awal Admin diharuskan login, setelah login admin dapat memanage data karyawan, sistem menampilkan data karyawan, lalu admin dapat memanage data jadwal, sistem menampilkan data karyawan, selanjutnya admin dapat memanage sms gateway, pada activity sms gateway dapat menerima dan mengirim sms, setelah itu admin dapat logout dari sistem.

\subsubsection{Tabel Relasi}

Terdapat banyak tabel relasi dalam sebuah database yang bernama sistem penjadwalan diantaranya tabel pegawai, log jadwal pegawai, jadwal dan sistem. Serta tabel Gammu berisi inbox, outbox, sentitems, pbk, pbk_group, outboxmultipart, phones serta daemons untuk pengolahan sms gateway. Tabel relasi ditunjukkan pada Gambar 4.

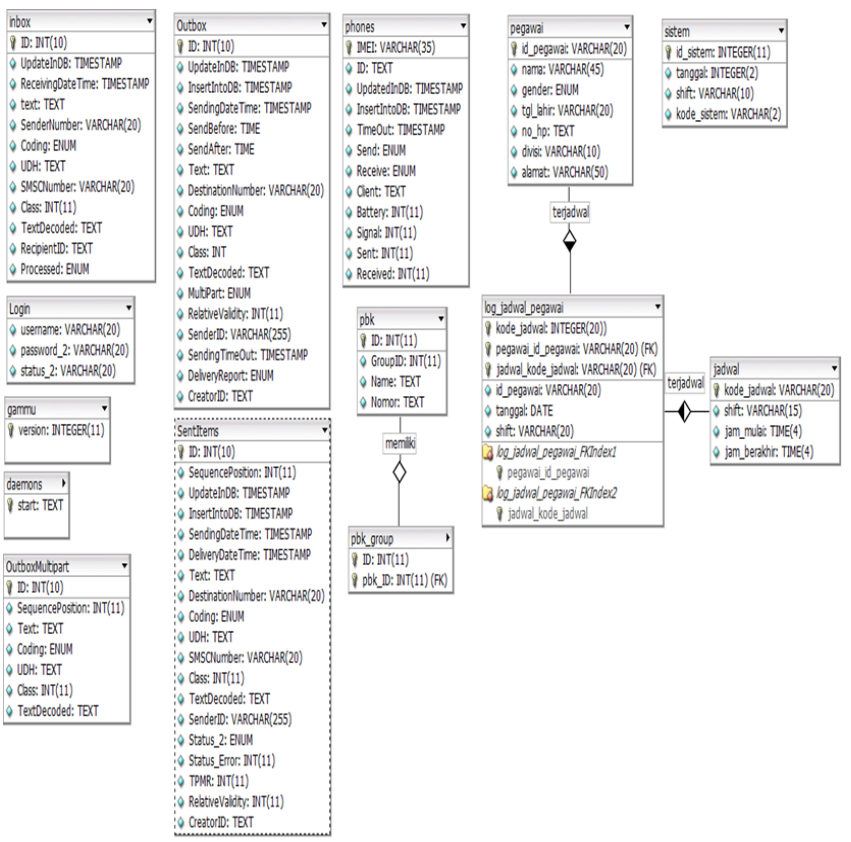

\section{Gambar 4. Tabel Relasi}

\subsection{Pengkodean (Coding)}

Bahasa pemrograman adalah bahasa disusun sesuai input dan output yang diinginkan dan bahasa dapat dikenali atau dimengerti oleh komputer. Coding menggunakan PHP (hypertext preprocessor) sebagai bahasa pemrogramannya, bootstrap sebagai templatenya, MySQL untuk databasenya dan SMS Gateway menggunakan gammu. Setelah itu masuk ke fase pengujian sistem.

\subsection{Pengujian Sistem}

Sistem diuji dengan dua tahap yaitu tahap pengujian sistem dengan blackbox dan tahap kedua dengan kuesioner. Tahap kuesioner dibagikan kepada 17 pegawai di PT. Air Mancur yang terdiri dari 1 Kepala Keamanan dan 16 pegawai serta 23 responden dipilih secara random. Total keseluruhan ada 40 kuesioner.

\section{HASIL DAN PEMBAHASAN}

Penelitian ini menghasilkan sistem penjadwalan yang berbasis website dan sms gateway. Bahasa pemrograman yang digunakan PHP, database menggunakan MySQL, Bootstrap sebagai user interface dan menggunakan GAMMU untuk mangelola sms gateway.

Halaman beranda admin berisi jumlah pegawai apabila diview details menampilkan keseluruhan data pegawai, Quick SMS menampilkan form untuk mengirim sms, Contact Us menampilkan data contact pabrik dan kantor pusat dan Company Profile menampilkan profil perusahaan. Halaman beranda admin ditunjukkan pada Gambar 5 .

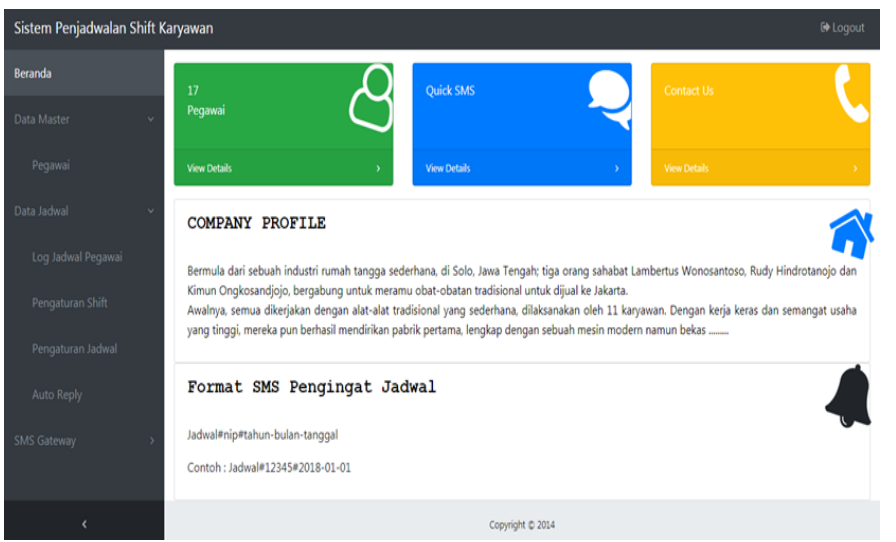

Gambar 5. Beranda Admin

Halaman Log Jadwal Pegawai menampilkan form shift berdasarkan bulan dan tahun yang dipilih. Ditunjukkan pada Gambar 6. 


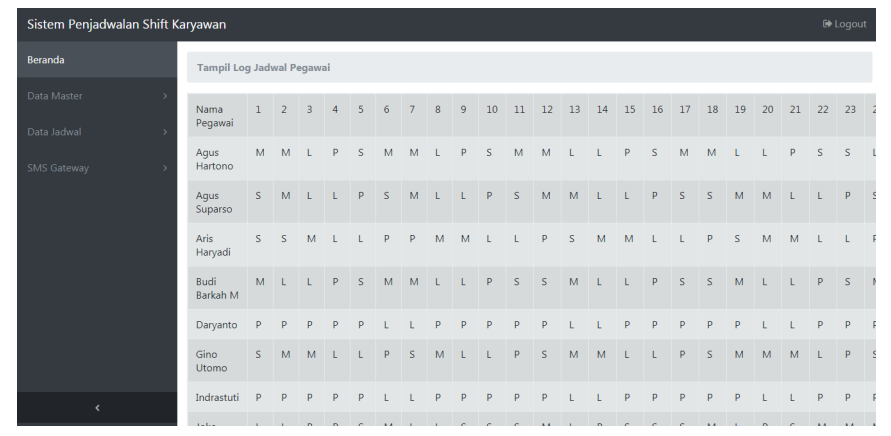

Gambar 6. Halaman Log Jadwal Pegawai

Halaman data pegawai menampilkan form untuk melihat pegawai yang ditunjukkan pada Gambar 7.
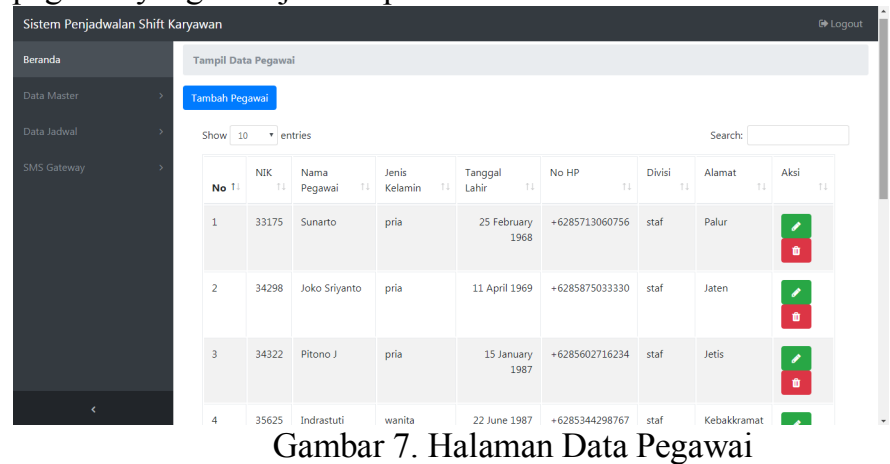

Apabila pegawai mengirimkan pesan untuk mengingatkan jadwal sesuai dengan format sms seperti berikut Jadwal\#id_pegawai\#tanggal kemudian dikirim ke nomor server, misal Jadwal\#36254\#2018-01-01 maka tampilan sms pengingat jadwal beserta jawabannya ditunjukkan pada Gambar 8.

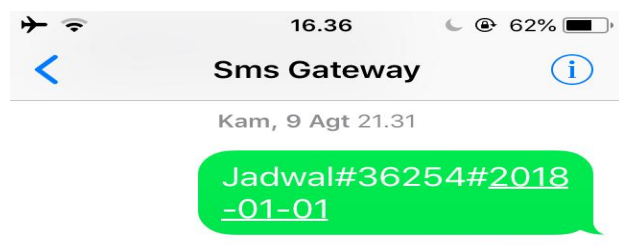

ID Pegawai atau tanggal tidak ditemukan

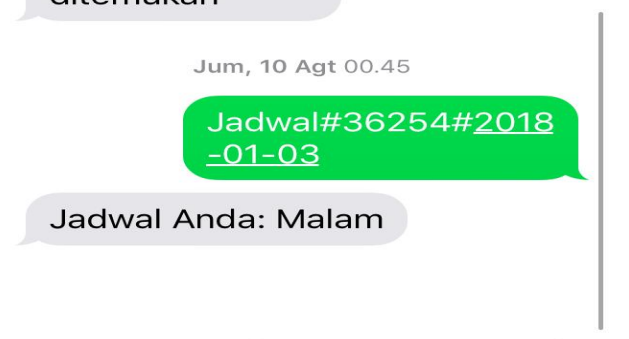

Gambar 8. Tampilan SMS Auto Reply
Pada tahapan pengujian sistem dilakukan 2 tahap yaitu pertama tahap pengujian black box dan tahap kedua yaitu kuesioner. Pengujian black box dilakukan langsung pada sistem untuk mengetahui sistem penjadwalan tersebut berjalan dengan lancar atau tidak. Tahap kuesioner meminta kepada calon pemakai sistem ini dan mengisi kuesioner yang telah disiapkan. Pengujian black box ditunjukkan pada Tabel 1.

Tabel 1. Pengujian Black Box

\begin{tabular}{|c|c|c|c|}
\hline Module/Fitur & Test Case & $\begin{array}{l}\text { Hasil yang } \\
\text { Diharapkan }\end{array}$ & Hasil \\
\hline \multirow[t]{2}{*}{ Login } & $\begin{array}{l}\text { User dan } \\
\text { Password } \\
\text { Benar }\end{array}$ & $\begin{array}{l}\text { User dapat } \\
\text { masuk ke } \\
\text { menu beranda }\end{array}$ & Valid \\
\hline & $\begin{array}{l}\text { User dan } \\
\text { Password } \\
\text { Salah }\end{array}$ & $\begin{array}{l}\text { User tidak } \\
\text { dapat masuk } \\
\text { ke menu } \\
\text { beranda }\end{array}$ & Valid \\
\hline \multirow[t]{3}{*}{$\begin{array}{l}\text { Pengolahan } \\
\text { Data Master } \\
\text { Pegawai }\end{array}$} & $\begin{array}{l}\text { Tombol } \\
\text { Tambah } \\
\text { Pegawai }\end{array}$ & $\begin{array}{l}\text { Menampilkan } \\
\text { halaman form } \\
\text { tambah } \\
\text { pegawai }\end{array}$ & Valid \\
\hline & $\begin{array}{l}\text { Klik Icon } \\
\text { Edit } \\
\text { Pegawai }\end{array}$ & $\begin{array}{l}\text { Menampilkan } \\
\text { halaman form } \\
\text { untuk ubah } \\
\text { data pegawai }\end{array}$ & Valid \\
\hline & $\begin{array}{l}\text { Klik Icon } \\
\text { Hapus } \\
\text { Pegawai }\end{array}$ & $\begin{array}{l}\text { Menampilkan } \\
\text { form untuk } \\
\text { hapus data } \\
\text { pegawai dan } \\
\text { muncul pop } \\
\text { up } \\
\text { persetujuan } \\
\text { hapus } \\
\text { pegawai }\end{array}$ & Valid \\
\hline \multirow[t]{3}{*}{$\begin{array}{l}\text { Pengolahan } \\
\text { Data Jadwal } \\
\text { Log Jadwal } \\
\text { Pegawai }\end{array}$} & $\begin{array}{l}\text { Tombol } \\
\text { Pilih Bulan } \\
\text { dan Tahun }\end{array}$ & $\begin{array}{l}\text { Menampilkan } \\
\text { halaman pilih } \\
\text { bulan dan } \\
\text { tahun yang } \\
\text { sesuai dipilih }\end{array}$ & Valid \\
\hline & $\begin{array}{l}\text { Tombol } \\
\text { Buat Jadwal }\end{array}$ & $\begin{array}{l}\text { Menampilkan } \\
\text { form untuk } \\
\text { mengenerate } \\
\text { jadwal atau } \\
\text { membuat } \\
\text { jadwal }\end{array}$ & Valid \\
\hline & $\begin{array}{l}\text { Tombol } \\
\text { Tampil } \\
\text { Tabel }\end{array}$ & $\begin{array}{l}\text { Menampilkan } \\
\text { form jadwal } \\
\text { dalam versi } \\
\text { tabel }\end{array}$ & Valid \\
\hline $\begin{array}{l}\text { Pengolahan } \\
\text { data jadwal } \\
\text { pengaturan } \\
\text { shift }\end{array}$ & $\begin{array}{l}\text { Klik icon } \\
\text { edit }\end{array}$ & $\begin{array}{l}\text { Menampilkan } \\
\text { form edit } \\
\text { pengaturan } \\
\text { shift }\end{array}$ & Valid \\
\hline
\end{tabular}




\begin{tabular}{|c|c|c|c|}
\hline & $\begin{array}{ll}\begin{array}{l}\text { Klik } \\
\text { delete }\end{array} & \text { icon }\end{array}$ & $\begin{array}{l}\text { Menampilkan } \\
\text { pop up hapus } \\
\text { data }\end{array}$ & Valid \\
\hline Module/Fitur & Test Case & $\begin{array}{c}\text { Hasil yang } \\
\text { Diharapkan }\end{array}$ & Hasil \\
\hline \multirow{3}{*}{$\begin{array}{l}\text { Pengolahan } \\
\text { data jadwal } \\
\text { pengaturan } \\
\text { jadwal }\end{array}$} & $\begin{array}{l}\text { Klik tombol } \\
\text { tambah } \\
\text { sistem }\end{array}$ & $\begin{array}{l}\text { Menampilkan } \\
\text { form tambah } \\
\text { sistem }\end{array}$ & Valid \\
\hline & $\begin{array}{l}\text { Klik icon } \\
\text { edit }\end{array}$ & $\begin{array}{l}\text { Menampilkan } \\
\text { form edit } \\
\text { pengaturan } \\
\text { jadwal }\end{array}$ & Valid \\
\hline & $\begin{array}{ll}\text { Klik } & \text { icon } \\
\text { delete }\end{array}$ & $\begin{array}{l}\text { Menampilkan } \\
\text { pop up hapus } \\
\text { data }\end{array}$ & Valid \\
\hline $\begin{array}{l}\text { Pengolahan } \\
\text { Data Jadwal } \\
\text { Auto reply }\end{array}$ & $\begin{array}{l}\text { Klik } \\
\text { cawang }\end{array}$ & $\begin{array}{l}\text { Menjalankan } \\
\text { mesin auto } \\
\text { reply }\end{array}$ & Valid \\
\hline \multirow[t]{3}{*}{$\begin{array}{l}\text { Pengolahan } \\
\text { SMS Gateway } \\
\text { Send SMS }\end{array}$} & $\begin{array}{lr}\text { Klik } & \text { drop } \\
\text { down } & \text { no } \\
\text { telepon } & \end{array}$ & $\begin{array}{l}\text { Menampilkan } \\
\text { daftar kontak } \\
\text { pegawai yang } \\
\text { terdaftar }\end{array}$ & Valid \\
\hline & $\begin{array}{ll}\text { Klik } & \text { isi } \\
\text { pesan } & \end{array}$ & $\begin{array}{l}\text { Menampilkan } \\
\text { form untuk } \\
\text { mengisi } \\
\text { pesan }\end{array}$ & Valid \\
\hline & $\begin{array}{l}\text { Klik } \\
\text { tombol } \\
\text { kirim pesan }\end{array}$ & $\begin{array}{l}\text { Untuk } \\
\text { mengirim } \\
\text { pesan yang } \\
\text { telah diisi }\end{array}$ & Valid \\
\hline $\begin{array}{l}\text { Pengolahan } \\
\text { SMS Gateway } \\
\text { Inbox }\end{array}$ & $\begin{array}{l}\text { Klik icon } \\
\text { delete }\end{array}$ & $\begin{array}{l}\text { Untuk } \\
\text { menghapus } \\
\text { pesan }\end{array}$ & Valid \\
\hline $\begin{array}{l}\text { Pengolahan } \\
\text { SMS Gateway } \\
\text { Outbox }\end{array}$ & $\begin{array}{l}\text { Menampilk } \\
\text { an pesan } \\
\text { yang tidak } \\
\text { terkirim }\end{array}$ & $\begin{array}{l}\text { Menampilkan } \\
\text { pesan yang } \\
\text { tidak terkirim } \\
\text { pada outbox }\end{array}$ & Valid \\
\hline $\begin{array}{l}\text { Pengolahan } \\
\text { SMS Gateway } \\
\text { Send Item }\end{array}$ & $\begin{array}{l}\text { Klik icon } \\
\text { delete }\end{array}$ & $\begin{array}{l}\text { Untuk } \\
\text { menghapus } \\
\text { pesan } \\
\text { terkirim }\end{array}$ & Valid \\
\hline Logout & $\begin{array}{l}\text { Klik } \\
\text { Tombol } \\
\text { Logout }\end{array}$ & $\begin{array}{l}\text { Muncul } \\
\text { notifikasi } \\
\text { logout }\end{array}$ & Valid \\
\hline
\end{tabular}

Dari Tabel 1. Pengujian black box menunjukkan bahwa sistem berjalan dengan baik dan tidak ada kesalahan dalam sistem penjadwalan shift jaga di PT. Air Mancur.

Pengujian kuesioner dibagikan kepada 1 kepala keamanan, 16 karyawan keamanan, dan 23 responden dipilih secara random dengan total sebanyak 40 responden. Pengujian kuesioner ini menggunakan perhitungan dengan rumus persamaan 1 sebagai berikut:

$$
\text { Persentase }=\frac{\sum \text { skor } \times 100 \%}{S \max }
$$

Untuk menghitung nilai Smax yaitu dengan rumus persamaan 2.

Smax $=\Sigma$ Responden $x 5 \ldots \ldots \ldots \ldots \ldots \ldots(2)$

Keterangan: 5 didapat dari nilai SS.

Jadi untuk nilai Smax dalam kuesioner ini yaitu $40 \times 5=$ 200.

Tabel 2. Hasil Kuesioner Pengujian Sistem Shift Jaga

\begin{tabular}{|c|c|c|c|c|c|c|c|c|}
\hline \multirow[t]{2}{*}{ No } & \multirow[t]{2}{*}{ Kode } & \multicolumn{5}{|c|}{ Jumlah Jawaban } & \multirow{2}{*}{$\begin{array}{l}\text { Total } \\
\text { Skor }\end{array}$} & \multirow{2}{*}{$\begin{array}{l}\text { Persent } \\
\text { ase }\end{array}$} \\
\hline & & $\begin{array}{l}\text { SS } \\
\text { (5) }\end{array}$ & $\begin{array}{l}S \\
\text { (4) }\end{array}$ & $\begin{array}{l}\mathbf{N} \\
\text { (3) }\end{array}$ & $\begin{array}{l}\text { TS } \\
\text { (2) }\end{array}$ & $\begin{array}{l}\text { STS } \\
\text { (1) }\end{array}$ & & \\
\hline 1. & $\mathrm{P} 1$ & 17 & 16 & 7 & 0 & 0 & 170 & $85 \%$ \\
\hline 2. & $\mathrm{P} 2$ & 24 & 12 & 4 & 0 & 0 & 180 & $90 \%$ \\
\hline 3. & P3 & 11 & 27 & 2 & 0 & 0 & 169 & $84,5 \%$ \\
\hline 4. & $\mathrm{P} 4$ & 28 & 9 & 3 & 0 & 0 & 185 & $92,5 \%$ \\
\hline 5. & P5 & 28 & 10 & 2 & 0 & 0 & 186 & $93 \%$ \\
\hline \multicolumn{8}{|c|}{ Rata-rata Persentase } & $89 \%$ \\
\hline
\end{tabular}

Grafik Kuesioner Pengujian Sistem

Penjadwalan Shift Jaga Keamanan Di PT. Air Mancur

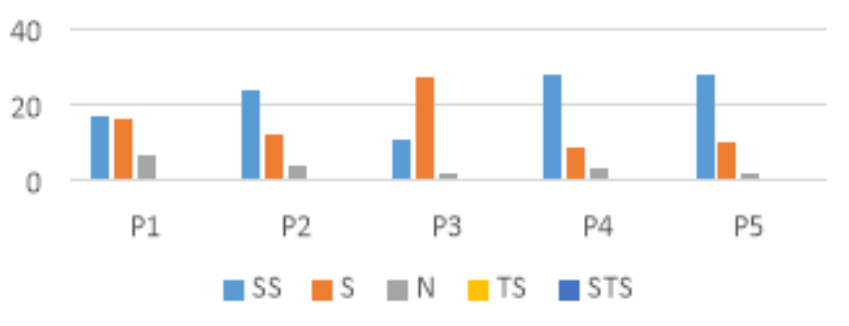

Gambar 9. Grafik kuesioner Pengujian Sistem Penjadwalan.

Keterangan:

P1: Tampilan login dan sistem menarik.

P2: Sistem penjadwalan mudah digunakan dan bekerja sesuai kebutuhan.

P3: SMS Gateway memudahkan untuk melihat jadwal shift jaga.

P4: Format sms mudah digunakan.

P5: Output yang dihasilkan sesuai yang diharapkan.

Pengujian black box menunjukkan bahwa sistem berjalan dengan baik dan tidak ada kesalahan dalam sistem penjadwalan shift jaga. Pengujian kuesioner didapatkan hasil sebesar $89 \%$ dari 40 responden yang menunjukkan bahwa sistem 
penjadwalan mudah digunakan dan memudahkan pengelolaan penjadwalan shift jaga di PT. Air Mancur oleh kepala keamanan (security).

\section{V.PENUTUP}

Penelitian ini menghasilkan sistem penjadwalan shift jaga berbasis web dan sms gateway dapat membantu kepala keamanan dalam mengelola penjadwalan shift jaga di PT. Air Mancur. Dari sistem tersebut terdapat menu beranda yang menampilkan fitur lihat pegawai, quick sms, contact us, company profile, dan format sms pengingat jadwal. Menu pegawai menampilkan data pegawai. Menu jadwal menampilkan log jadwal pegawai, pengaturan shift dan auto reply machine. Menu sms gateway menampilkan send sms, inbox, outbox dan send items. Pengujian black box menunjukkan sistem berjalan dengan baik dan tidak ada kesalahan dalam sistem. Pengujian kuesioner menghasilkan persentase $85 \%$ dari $\mathrm{P} 1,90 \%$ dari $\mathrm{P} 2,84.5 \%$ dari $\mathrm{P} 3,92.5 \%$ dari P4 dan 93\% dari P5 dengan total rata-rata persentase sebesar $89 \%$. Saran untuk penelitian yang sudah dilakukan sebaiknya menambahkan format pergantian shift pada sms gateway, menambahkan fitur form printout tabel penjadwalan shift dan fitur-fitur lainnya sesuai dengan kebutuhan.

\section{Daftar Pustaka}

[1] Setyawan, B. (2016). Strategy Development Policy Course Information For Submission Of Application Based Sms Gateway To High School Teacher Training And Education (STKIP PGRI Pacitan). Publikasi Internasional, 1(1).

[2] Supriyono, H., Saputro, N. A., \& Pradessya, R. A. (2016). Rancang Bangun Sistem Informasi Manajemen Presensi Berbasis SMS Gateway (Studi Kasus: SMP Muhammadiyah 1 Kartasura).

[3] Aswiya, T. A., \& Waryanto, N. H. (2017). SISTEM INFORMASI OPERATOR LAYANAN INTERNET MAHASISWA UNY BERBASIS WEBSITE DILENGKAPI DENGAN SMS GATEWAY. Jurnal Matematika-S1, 6(1), 24-33.

[4] Muchtar, A. F. (2015). Aplikasi Sistem Informasi Perkumpulan Kepala Keluarga Berbasis SMS Gateway (Studi Kasus: Wilayah RW-IV Kelurahan Kratonan) (Doctoral dissertation, Universitas Muhammadiyah Surakarta).

[5] Kurniawan, Y. I. (2018). PEMBANGUNAN WEBSITE INFORMASI SEKOLAH DI SMA NEGERI KERJO, KARANGANYAR. JABDIPAMAS (Jurnal Pengabdian Kepada Masyarakat), 2(1), 116-129.

[6] Zuhaeri, Andi, 2018, Penjadwalan Proses Sistem Operasi Komputer, [pdf],

(http://www.academia.edu/8785380/Penjadwalan_Proses_Sistem_Opera si_Komputer.pdf, diakses tanggal 01 oktober 2018).

[7] Alhifi dan hindarto, (2018), Jurnal Aplikasi Pemesanan Produk Berbasis SMS Gateway di PT Sinar Sosro, [pdf], (http://www.academia.edu/15289717/Jurnal Aplikasi Pemesanan Prod uk_Berbasis_SMS_Gateway_di_PT_Sinar_Sosro.pdf, diakses tanggal 01 oktober 2018).

[8] Pressman RS. (2010). Software Engineering: A Practitioner's Approach, $7^{\text {th }}$ ed.Mc Graw Hill. 